\title{
SOCIO-PHILOSOPHICAL ANALYSIS OF OBJECTIVE FACTORS OF MODERNIZATION OF EDUCATION SYSTEM IN RUSSIA FROM THE STANDPOINT OF NATIONAL SECURITY PRINCIPLES
}

\begin{abstract}
The article reveals the nature and essence of objective factors, the nature of their impact on education, the emergence of possible risks and threats in the system of education and the training of new generations of the country from the standpoint of their safe existence in changing social conditions. Education is a process in which there is a purposeful translation of the system of social relations, while it makes it possible to form in a person significant for social norms of behaviour and activity, which together reproduces the entire system of socio-cultural relations. However, there is a high dynamics of development in society at all levels of the system of relationships, so many factors of different levels affect education. The purpose of the study is to determine the current external and internal factors of the modernization of the Russian education system. To achieve this goal, it is necessary to solve problems based on a socio-philosophical understanding of the factors of modernization of the educational space. An objective analysis of the current crisis in the national education system shows that it needs to be modernized.
\end{abstract}

Keywords: modernization, education system, objective factor, national security.

Introduction

Currently, the analysis of the ideas of modernization of national education is presented in numerous works of scientists, namely in the works of V. Baidenko (2010), N. N. Bolshakov (2007), A. P. Valitskaya (2010), E. F. Moros and V. V. Goncharov (2020), A. S. Savvin (2012), O. N. Smolin (2011), N. M. Churinov (2007). However, the complex of objective factors of modernization of the education system in Russia from the point of view of ensuring national security is not currently identified. Permanent reform of education over the last quarter of a century without improving its quality is carried out in isolation from the real needs of the individual, society and the state. It does not strengthen, but rather weakens the security of both the education system and the national security of Russia as a whole. Socio-philosophical understanding of the objective factors of modernization of the modern education system in Russia will allow us to deal with its systematic development, determine the main goals and ways to strengthen it and its long-term development.

\section{Methodology}

The research is based on a philosophical methodology. In the preparation of this article, General scientific and special socio-philosophical research methods were used: analysis of sci- 
entific literature, comparative, system and complex analysis, induction, deduction, generalization, the method of historical Parallels, forecasting and modelling. All the above methods allowed us to identify external and internal objective factors of modernization of the education system, identify dangerous crisis phenomena for the Russian education sector, and develop recommendations for their overcoming and prevention.

\section{Research Results and \\ Discussions}

Today in Russia, there is a completely new system of external and internal challenges and threats to the national security of society, the state and the individual, as well as the security of the educational space, which is not directly related to the traditional image of the enemy. Purposeful introduction of globalist types of behaviour and thinking into the Russian education system, education reform focused on the standards of Western countries, imitation of Western media, etc. - all this and much more negatively affects Russian society and gradually leads to the loss of national identity.

This, first of all, relates to the issue of waging an information and psychological war against Russia, which involves the so-called "intangible weapons" (or the concept of "soft power"). This term means that the impact on people occurs through the use of special methods and means of aggressive manipulation of public consciousness to demoralize and latent control the behaviour of individuals, social groups, and public authorities, including the armed forces, law enforcement agencies, and special services. All this became possible due to the active activity of the media, grant support, and non-profit foundations that use technological achievements to introduce destructive ideas, standards, and ways of thinking into the public consciousness.

In addition to national culture, morals, and traditions, there is also intelligence and knowledge. In this regard, it is possible to designate as a certain set, mainly scientific, ideological, information security, intellectual (educational) security of society, which is a significant component of national security.

According to A. V. Vozzhenikov (2000), such security implies the protection of intellecttual values and national cultural heritage and the protection of an adequate traditional ideology of society (p. 25). We see education as the basic element of protecting the national cultural heritage as the main tool for forming an intellectually developed individual and society as a whole.

We fully agree with the opinion of V. V. Mironov (2008), noting that the most dangerous are the threats leading to the decline in education, the decline of scientific potential and intellectual level of society, loss of moral values, acting directly conditions affecting the security of the state as a whole (p. 68). Modern changes in socio-political realities, new economic trends (in the context of anti-Russian sanctions) lead to the need for serious social changes that objectively make the issue of reforming education one of the main problems for Russian society, on the resolution of which, for the most part, its subsequent preservation and development depend.

Education is a controlled social process in which a permanent translation of the corresponding system of relations is carried out, and in person, it allows you to form socially important qualities, norms and rules of behaviour and activity, which, in turn, ensure the reproduction of the entire system of socio-cultural relations. From the point of view of preserving the security of the 
state, it is education that acquires special, key importance.

Currently, the transformation and (or) modernization of the national education system, taking into account its long-term and, as it already seems to the scientific and pedagogical community, endless, unsystematic and uncontrolled reform, should be interpreted as a long-term crisis of the education system. In connection with these circumstances, there is a need to search for reasons and options for overcoming the current crisis stage in the development of national education based on the principles of ensuring national security (Belyaeva, 2012, p. 124).

This search, according to the author, is associated with a socio-philosophical analysis of the problems and opportunities of education, which allows identifying essential contradictions (for example, between the growing private nature of the appropriation of means of production and the public nature of the educational system), correlating them with real social practice and making an adequate and objective prediction.

From the perspective of social philosophy along with the philosophy of education acquires a new status - a prognostic branches of humanitarian knowledge and expertise is able to determine the prospects of development of not only education but also national security of our country, sustainable development of the state in the increasingly complex global relationships.

At the same time, the modern information society is becoming more and more dynamic at all levels of its organization - global, international, national, at the level of individual spheres of the country's life - economic, political, informational, etc. In this regard, education is objectively affected by many factors of different levels, different strengths, and different vectors.

First, these are the factors of increasing glo- balization of the world space, which can unify the educational process of different countries, either on the model of a unipolar or multipolar world.

Second, there are a number of international agreements (for example, the Bologna agreement) that dictate changes in the structure, content of education, and teaching methods based on Western models, essentially ignoring the specifics of national and state educational systems.

Third, these are macroeconomic and microeconomic factors within the country, which can significantly affect, for example, the education budget, the different distribution and redistribution of financial and economic resources at different levels and branches of the educational system in different regions of the country, determine the growth of differences in the level of urban and rural education, small cities and megacities, etc. In relation to the Russian education system, all these factors are external, objectively acting and largely changing the quality of educational relations and the system of education management.

Awareness of the fact that the deepening of existing contradictions is an objective factor in the modernization of the Russian education system, indicating the inability of the modern education system, which implements a specific type of educational practice in the created educational paradigm, to solve the existing contradictions, led to the conclusion that the prevailing type of educational practice requires replacement.

The complexity of accounting for objective factors consists of their different levels, diversity, and often in the inconsistency of the impact of heterogeneous factors. This leads to the formation of complex, ambiguous, often conflicting situations in the educational environment and in the educational space of Russia. Leads to defor- 
mation of the educational system as a whole, creates risks, threats and demands to comprehend the situation not only from the standpoint of the quality of the organization of the entire system in a complex educational environment of the country, but also from the standpoint of safety education, and national security of the Russian Federation because the scope of education has the fundamental role of the current and future generations for productive lives in society and the realization of the power of the human factor in the sustainable development of the state.

The initial moments of overcoming the crisis of education from the standpoint of the national philosophical and educational paradigm are fundamental guidelines in the development of knowledge, humanisation of thinking and continuity of the educational process, which, in the form of meaningful foundations for building new educational systems, contribute to optimizing the process of mastering a new educational paradigm.

Helping to solve the growing contradictions in the relationship "education - society", "education - science", "education - culture", this triad provides a high-quality socio-pedagogical process of education reform in the form of human inclusion in society.

Objective impacts can have a pronounced positive character. Thus, the factor of humanisation in the process of modernizing modern education provides for overcoming a narrowly scientific, technocratic, mechanistic approach to understanding education; solves the problem of subjectivity in education as a way to gain a creative, active position of a person in life; solves the problem of losing the integrity of being a modern person. Indeed, the very concept of "education" gives an idea that the person himself is both the object and subject of education and therefore of humanisation.

Humanisation is a tool for overcoming the alienation characteristic of modern society. Humanisation in education generates the formation of humanitarian thinking as the basis of human nature (Veryaskina, 1997, pp. 204-211).

Education is not only a tool but also a goal of human development. Education accompanies a person throughout his life, forcing him to continuously learn and learn new things in a complex and rapidly changing world. The organization of continuous education is also a necessary modernization that allows not only to overcome the discreteness of educational levels by optimizing the continuity in the acquisition of knowledge but also to provide conditions for meeting the educational needs of the individual at all stages of his life.

This significantly increases the role of selfeducation as a means of self-development and self-realization, which in turn, is essential for the formation of educational policies aimed at the formation and development of a system of ensuring national security of society, state and personality.

Education "includes" a person in a specific historical and cultural framework, sets norms and rules of social behaviour and professional activity, and therefore the continuity of education allows you to adjust the process of learning new knowledge and skills. Education throughout life determines the individual's desire for permanent self - determination and self-development, and it is very important that this process does not result in the formation of exclusively independent, autonomous individuals-individualists. Therefore, this area of education also needs constant monitoring. 
The quality of social and professional characteristics of the individual responsible for its involvement in socio-political and economic processes is a measure of education, and more specifically, of the "educational product" being formed. In this sense, education is aimed at the development of society through the reproduction of social norms as the embodiment of social patterns in public institutions, structures, relationships, processes, as well as at the reproduction and development of the individual as a carrier of cultural patterns (Wolfson, 1991, pp. 124-130).

Education, in fact, is responsible for the formation of a subjective picture of the objective world, hence the requirements of a worldview and epistemological nature. The ideological aspect of the requirements for education as the formation of a subjective picture of the objective world is associated with both General cultural norms and values and with ideological representations in society at a specific historical stage of its development.

Epistemological requirements presuppose the formation of a subjective picture of the world that would coincide as much as possible with the objective picture of the world. And the effectiveness and efficiency of educational activities depend on how exactly they will coincide.

An important role is played by the question of "belonging" to educational activities and the nature of socio-cultural interaction of the subjects of this activity. Issues of professional content of education, its social significance and responsibility form the relevant state institutions, which should be responsible for compliance of the content of education with the state policy in this area and for timely control over the activities of other subjects of education. Depending on this, the socio-cultural type of education is distinguished not only as a cultural transfer but also as a cultural producer, and, consequently, creating a person as a basic element of social development.

The formation of the content of education from the standpoint of its socio-cultural type captures the interaction and mutual development of such elements as educational knowledge, humanitarian thinking, and lifelong learning. With this approach, the focus of the socio-cultural type of education is on the individual with his desire for self-development and self-realization, and the educational process itself is an instrument for forming the essential qualities and needs of a person. These qualities include both an objective attitude to the external world, which, in turn, acts as the driving force of his life, and the inner world of the individual. The dialectic of the mutual transition of the external (objective) and internal (subjective), implemented in the process of human activity, implies the unlimited development of its essential qualities.

The formation of the content part of education from the standpoint of its socio-cultural type involves the use of adequate educational technologies, the purpose of which is the formation of such universal superprofessional competencies as teamwork, critical, system thinking, and others.

And "if the educational process is built on the desire to develop the thinking of the emerging person, then this can only be done through an appeal not to the thing, but to another thinking" (Dneprov, 2001, p. 81).

Here we come to a new understanding of the content of education as the formation of personal competencies, which ultimately individualizes its assignment.

And as a result, it changes the entire educational process.

Socio-philosophical understanding of the educational process leads to the need to take into 
account the cultural factor when individualizing the assignment of educational results. In this sense, along with professional competencies and General cultural competencies, the formation of supra - professional, universal competencies is a necessary stage of humanisation of education, since the skills they set for working with people, creative thinking, effective professional and intercultural communication, and project work are responsible for the formation of a full-fledged personality. At the same time, it is taken into account that this person exists and reveals his / her social competence in a certain cultural space. And thanks to modern information technologies, this space is expanding to a global level.

In our study, it is vital that the social-philosophical understanding of the educational space taking into account the factor of culture allows preserving national identity and integrity of the state, helps to implement education policy so that she found understanding and support among the population.

If we start analyzing the process of modernization of Russian education based on objective factors, we can say that there are two points of view on the social and cultural opportunities for the development of society. First, the change in the educational environment follows the path of its socio-cultural essence. In other words, it searches for certain concepts that are later used for its design. Secondly, we consider the readiness of Russian society to accept such potential and adopt it. This is mainly about the contradictions between the new type of education that Russian society needs and the existing old model of education that has been inherent in the system for decades. Therefore, the reform of society and the education system should go simultaneously, and this will manifest a certain socio-cultural resonance. In this regard, it is worth introducing the concept of "points of development". By points of development, we will understand the relationship between society and the education system. One such point will be the quality of education since it immediately expresses both the result of activities in the field of education and the potential for social development (Kolin, 2013, p. 45).

It is important to note that the abovementioned point of development cannot be reduced to literacy, competence acquisition, or education. The listed indicators of the result of educational activity not only reflect its quality but also describe the system of relations individual production - culture - society. It is not for nothing that in the current conditions, education is called a treasure that needs to be found and extracted. In other words, education is not limited to performing its functions to society; its main goal is to preserve and ensure the social system. The social phenomenon of education is considered only from such positions.

As any other educational scheme, the possibility of sustainable social development is expressed. From the point of view of this position, the educational process leads to the strengthening of the integrity of society and the development of its self-organization. In addition, there is preservation and reproduction of new social values that acquire qualitatively different ideals of education, as a result of which society gets additional opportunities to compete within the framework of world civilization (Lednev, 2011, p. 40).

If we talk about the structure of the quality of education and its impact on the individual, it can be represented as a pyramid hierarchy with many different levels. The construction of such a structure is based on the philosophy of education, which is reflected in the anthropological approach. This approach is aimed at self-determination, design and implementation of each indi- 
vidual. At the very bottom of such a pyramid will be common abilities for all since they relate activities to needs. With the help of subject-specific, General-subject competencies to the supersubject competencies that are key. At the top of the pyramid are social confidence, the ability to compete, and cultural creativity that are in demand by society and culture, accumulated in self-realization.

Note that this understanding of the basic elements of a quality education system cannot be considered human as the most important element of the socio-educational structure from the point of view of developing social development. On the one hand, we are talking about the presence of two important aspects that guide the vector of success in the mutually dependent influence of the individual and society. On the other hand, innovation, project thinking and culture act both as the social opportunities that education provides for each individual and as the main factors of sustainable social development, in which the individual is the main driving force.

But the impact of negative objective factors is also great. For example, the introduction of globalist types of behaviour and thinking focused on the standards of organization of life in Western countries into the domestic education system, imitation of Western media in promoting standards of global consumerism, devaluation of spiritual and moral values, and forgetting the principles and knowledge of the General scientific picture of the world negatively affects the public consciousness of Russian society.

Such influence disorients the behaviour of citizens, disrupts the necessary consolidation of the population's activities on the domestic principles of a common cause, and gradually leads to the loss of national identity, i.e., to the undermining of the country's national security. Modern changes in socio-political realities, complex international anti-Russian sanctions for Russia and growing information wars lead to the need to increase the stability and intellectual level of the country's human potential, which is directly related to the modernization of the education system based on its own socio-cultural traditions and the best achievements of modern world pedagogical experience.

It is important to note that not only law enforcement agencies, the armed forces and special services, but also various public organizations, public institutions and the media provide counteraction to external aggressions that violate the security of society and the state and their prevention. Note that various organizations and social groups of civil society form two large groups. The first group includes secular groups and organizations, and the second - religious, which is reflected in the legislation of the Russian Federation.

The objective factors of changes in the educational environment of the Russian Federation are also influenced by the fact that the prosperity of the state is provided primarily by relations between representatives of different faiths and nationalities. They are the basis for the stable development of society in the Russian Federation. In order to preserve the unique mentality of all peoples living in Russia, it is important not to lose the existing traditions and culture of small ethnic groups. Unification of culture will cause serious harm to the development of Russian society.

It is worth noting a sad fact. In the Russian Federation, at the present stage of its development, mass culture is widespread almost everywhere. Russian mass culture exactly copies its Western counterparts (movies, TV series, music), and there is widespread propaganda of alien 
images and patterns of behaviour. An important role in this is played by the mass media, which are budgeted from the state Treasury. This situation is fundamentally wrong and does not correspond to the principles of an independent state.

To solve this problem, it is necessary to create such associations and organizations that would ensure security in the field of information. Coordination between the state and civil society of their interests in the sphere of social interests, relations between various social groups, including information security, will result in the creation of a more effective system for ensuring the security of the state and the nation.

The value of civil society institutions lies in the fact that they are not dependent on state structures. They are independently engaged in developing and making decisions on a particular problem. If we talk about religious and secular associations, such organizations are created artificially and gather under their own auspices conjuncturists. Society does not accept such formal institutions of civil society, and people openly dislike them. Therefore, instead of consolidation and unity, we get the separation of social groups. Society needs models of education and development that are understood and accepted by different social groups. People intuitively feel that they need to be together and together, so you should think about supporting and implementing this feeling.

V. A. Avksentiev (2006) notes that a modern resident of the Russian Federation comes to religion and religious institutions not for the purpose of spiritual search, but with a great desire to feel their ethnic and cultural identity. This example clearly shows that at present, the unification of the mentality of all peoples living in Russia is proceeding at an active pace (pp. 41-47).

Agreeing with the opinion of this scientist, we believe that the Russian nation intuitively feels the impending threats, so some members of society are looking for support from authorities, looking for answers to emerging questions in religion.

At the same time, in our opinion, it is necessary to actively develop in society unifying Patriotic feelings, which, as it seems to us, are significantly based on religious views. In General, the unity of the information, national and educational space in the Russian Federation is ensured by the activities of formal and informal, Amateur associations, which are represented by historical clubs, Patriotic, religious and cultural organizations. All of the above forms the basis of the spirituality of Russian society creates a unified information environment for maintaining the mentality of the peoples inhabiting Russia. In addition, the activity of such associations is most acute and necessary during crises, when society and the state begin to confront each other. The contradictions in politics, society, and Economics that manifest themselves in such times are smoothed out by maintaining a dialogue between civil society institutions and state authorities.

It should be emphasized that currently, popular mass media play an important role in the world community and in public relations. They also educate and educate the younger generation, but not always in a positive and constructive way. In our opinion, within the framework of the state educational policy, it is necessary to develop mechanisms that prevent the negative influence of the media on the formation of personality.

Currently, at the state level, attempts are being made to protect children from information that can harm their health (mainly by limiting the time of broadcasting a number of programs, blocking access to certain Internet resources, 
etc.), but this is not enough, work in the information space should be carried out in a comprehensive and systematic manner.

A society with a highly developed system of information technology substitutes mass culture for national culture. Scientists who have studied the problem of the relationship and mutual influence of mass media and mass culture since the middle of the last century Express their concerns and sound the alarm. At the moment, the current state of Affairs in modern Russia leads to the destruction of the nation's inherent types of thinking, the destruction of historically established cultural, ethical norms and values.

The emergence of the global Internet, which now covers almost all segments of the population in all countries and continents, globalizes relations between social groups and individuals, has an increasing impact not only on the consciousness of the entire population of the planet but also on the self-consciousness of each individual.

The activity of the information space and cybersystems has the main goal of destroying moral orientation, stimulating primitive biological instincts. Under the influence of information and communication technologies, the entire population turns into a "world village", which is limited by the interests of its narrow group and cannot notice the impending threats and challenges of modern society. Low-quality information that is widely available to Internet users, destructive and delinquent video games, movies, TV series, websites and portals contain propaganda of deviant behaviour and pose a threat to our society. Therefore, in order to ensure the information and psychological security of society, it is necessary to control the virtual space.

Currently, an attempt is being made to create a virtual supranational mentality. Actions aimed at achieving this goal have been actively carried out over the past decades. Such activities are aimed at creating tolerant models and stereotypes of behaviour and thinking, which are essential characteristics of personal and group identity within all faiths, nationalities and cultures.

This is largely facilitated by specially developed models that are introduced into the consciousness of each person through the media, which has tragic consequences in Russian society. Modern society has almost lost its moral and spiritual guidelines, which was a consequence of Russian ideals, including those cultivated in the Soviet Union. The new educational environment creates values that are included in the process of disintegration. In this regard, the most acute conflict is between the officially imposed mass culture and the financially, politically and economically impoverished population. All this is hard for the creatively active part of the denying moral and spiritual guidelines, and the negative aspects of life aimed at spoiling Russia, propagandize the media. The media creates a false and virtual space that is not connected with reality and is full of destructive information. The existence of such a false space causes serious damage to Russia in the sphere of national, psychological and informational information.

Due to the lack of state censorship, the promotion of cultural values that are not peculiar to the peoples of Russia is actively carried out, and only the interests of narrow groups are put at the forefront. Such activities are funded and encouraged by the special services of anti-Russian opponents and competitors in the international arena, who introduce unified stereotypes, values and patterns of behaviour into the minds of the residents of the Russian Federation. The current state of Affairs is a threat to the national security of the Russian Federation. Today, the provision 
of information and educational security in Russia is very numerous. The state needs to create conditions that aim to convey complete and truthful information to every member of society.

To preserve the values of education and upbringing, it is impossible to do without stateowned, patriotically oriented mass media. For the purpose of the comprehensive development of the individual and a healthy society, a unified information space should be created. In the process of creating and designing such a unified space, it is necessary to use electronic media in every possible way. This situation will be contrasted with the destructive media spread on the Internet, whose activities are aimed at destroying the traditional Russian mentality, promoting antisocial ideology, religious sects and extremist groups. At the present time is a priority, the monitoring and verification of the Internet space. It is worth noting that specialists carry out such work. However, an insufficient number of highly qualified specialists of the armed forces of the Russian Federation, law enforcement agencies and special services are involved in solving the problem.

The Russian Federation needs such mass media that would be engaged in Patriotic education, education of the population of the country and at the same time, ensure its national security.

It is worth emphasizing that we should counteract all diversions carried out against the Russian Federation aimed at undermining national security and carrying out network wars and cyber attacks. In contrast to the prevailing commercial media, government officials should create Treasury-funded Newspapers and magazines that highlight intellectual achievements, ethical, moral, and aesthetic norms and values.

Taking into account the mentioned objective factors, the crisis of education acts as a kind of reflection of the multidimensional, multi-level, largely uncertain and contradictory process of modern transformation of society itself. It is in this transformation of the global society of the $21^{\text {st }}$ century with its ambiguous strategies that objective impacts on the pedagogical sphere can be multi-vector and even chaotic. This makes it necessary to analyze and group objective factors from the standpoint of both ensuring Russia's national security and the principles of preserving security from destructive processes and the security of Russian education.

\section{Conclusion}

Thus, socio-philosophical understanding of objective factors of modernization of the education system external (global and international) and internal nature, must be implemented on the basis of the main principles of Russia's national security: guaranteeing its sovereignty; the country's sustainable development due to the high intellectual, civic, spiritual and cultural potential of the population; creative labour enthusiasm of citizens defined by the state ensured a decent standard of living human creative labour.

The objectively determined state of the crisis in education leads to an awareness of the need for optimal modernization of the system and concept of Russian education. Modern educational policy should be largely aimed at overcoming the crisis, taking into account the global crisis of general civilization, the crisis of international social systems, the systemic crisis of the Institute of education, and the crisis of a number of sectors of public life. Ways to overcome the crisis should be understood at the socio-philosophical level and included in the content of the socio-philosophical concepts of the development of domestic education and the concept of educa- 
tional security.

\section{References}

Avksentiev, V. A. (2006). Konfessional'naya identichnost $v$ konfliktnom regione (Confessional Identity in the Conflict Region, in Russian). Sociological Research, 10, 41-47.

Baidenko, V. (2010). Obrazovatelnyi standart kak filosofskaya i naychno-teoreticheskaya problema (Educational Standard as a Philosophical and Scientific-Theoretical Problem, in Russian). Alma Mater, 10, 16-22.

Belyaeva, L. A. (2012). Filosofiya obrazovaniya $v$ nachale tret'ego tysacheletiya (Philosophy of Education at the Beginning of the Third Millennium, in Russian). XXI Century: The Future of Russia in the Philosophical Dimension, 21-125.

Bolshakov, N. N. (2007). Analiz riskov natsional'noi bezopasnosti Rossii voznikayushchikh $v$ popytkakh modernizatsii vysshego obrazovaniya (Analysis of Russian National Security Risks Arising in Attempts to Modernize Higher Education, in Russian). State-power-security, part 2, 88 .

Churinov, N. M. (2007). Rossiiskaya sistema obrazovaniya kak faktor stabilizatsii obshchestvenoi zhizni (Russian System of Education as a Factor of Stabilization of Social Life, in Russian). Philosophy of Education, 1, 23-74.

Dneprov, E. D. (2001). Sotsial'nye i naychnye istoki "Pedagogicheskoi anthropologii” K. D.Uchinskogo (Social and Scientific Sources of "Pedagogical Anthropology" by K. D. Ushinsky, in Rus- sian). Proceedings of the Department of Pedagogy and History of Education and Pedagogical Anthropology, 2, 5164.

Kolin, K. K. (2013). Prioritetnya napravlenia razvitia sistemy obucheniya $i$ vospitaniya (Priority Directions of Development of the System of Education and Upbringing, in Russian). Synergetics and Educational Process, 47-54.

Lednev, B. C. (2011). Soderzanie obrazovania: sushchnosti, struktura $i$ perspektivi (Content of Education: Essence, Structure, Prospects, in Russian). Moscow: Nauka.

Mironov, B. B. (2008). Obrazovanie kak osnovopolagayushchaya tsennosti $i$ opasnosti unifikatsii (Education as a Fundamental Cultural Value and the Dangers of Unification, in Russian). World Public Forum "Dialogue of Civilizations". Vestnik, 2(43), 16-25.

Moros E., \& Goncharov, V. (2020). Modern Dangers in the Development of the Russian Education System and Ways to Overcome Them: Socio-Philosophical Analysis. Wisdom, 2(15), 114-128.

Savvin, A. C. (2012). Bolonski protsess i natsional'naya sistema obrazovaniya (The Bologna Process and the National Education System, in Russian). Philosophy of Education, 2(41), 43-48.

Smolin, O. N. (2011). Sotsial'no-filosofskie aspekty obrazovatel'noi politiki $v$ usloviyakh radikal'noi trasformatsii rossiiskogo obshchestva (Socio-Philosophical Aspects of Educational Policy in the Conditions of Radical Transformation of Russian Society, in Russian). Moscow: Nauka. 
Valitskaya, A. P. (2010). Filosofskie osnovaniya sovremenoi paradigmy obrazovaniya (Philosophical Foundations of the Modern Paradigm of Education, in Russian). Pedagogy, 3, 12-18.

Veryaskina, V. P. (1997). Evristicheskie vozmozhnosti sinergeticheskogo podkhoda v filosofii obrazovaniya (Heuristic Possibilities of the Synergetic Approach in the Philosophy of Education, in Russian). Synergetics and Education, 204211.
Vozzhenikov, A. V. (2000). Osnovnye kontseptual'nye polozheniya natsional'noi bezopasnosti Rossii v XXI veke (Basic Conceptual Provisions of the National Security of Russia in the XXI Century, in Russian). Moscow: EDAS PAK.

Wolfson, B. L. (1991) Sravnitel'naya pedagogi$\mathrm{ka}$ : istoriya i sovremennye problemy (Comparative Pedagogy: History and Modern Problems, in Russian). Soviet Pedagogy, 1, 124-130. 